\title{
Multidimensional profile of elderly participants of an influenza vaccination campaign
}

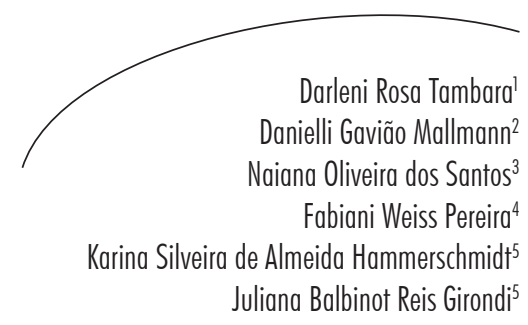

\section{Abstract}

Objective: To describe the multidimensional profile of the living conditions of a group of elderly participants of an influenza vaccination campaign. Method: A cross-sectional study was performed, with data collection carried out between April and May 2010. A convenience sample of 225 elderly persons from 13 municipal health centers in Uruguaiana in the state of Rio Grande do Sul and vaccinated in the national influenza vaccination campaign was used. Subjects were interviewed using a structured script and statistical analysis of the data was performed. Results: Most elderly persons were female (62.2\%), aged between 60 and 70 years (64.8\%), married (40.4\%), had a monthly income below the level of poverty (55.5\%), used the Unified Health System $(79.1 \%)$ and reported having good health (63.5\%). Watching TV was one of the most common leisure activities. All the elderly women participants and $94.1 \%$ of the total sample were religious, with the catholic and evangelical faiths reported most frequently. Participants in the study described proper nutrition and a healthy lifestyle as being most likely to result in longevity. Family and health were among the most important factors in the life of the elderly individuals. Alcoholism, drugs, crime, violence, and political corruption were cited as the main problems for Brazil. All seniors were independent in basic and instrumental activities of daily living. Conclusion: Understanding the living conditions of the elderly assists healthcare professionals and supports the implementation and development of appropriate public policies for this population group.

Hospital Santa Casa de Caridade de Uruguaiana, Unidade de Terapia Intensiva Neonatal. Uruguaiana, RS, Brasil.

2 Universidade Federal de Pernambuco, Centro de Ciências da Saúde, Departamento de Enfermagem, Programa de Pós-graduação em Enfermagem. Recife, PE, Brasil.

3 Universidade Federal do Rio Grande do Sul, Escola de Enfermagem, Programa de Pós-graduação em Enfermagem. Porto Alegre, RS, Brasil.

4 Universidade Federal do Rio Grande, Escola de Enfermagem, Programa de Pós-graduação em Enfermagem. Rio Grande, RS, Brasil.

5 Universidade Federal de Santa Catarina, Centro de Ciências da Saúde, Departamento de Enfermagem. Florianópolis, SC, Brasil.

Correspondence

Karina Silveira de Almeida Hammerschmidt

E-mail: karina.h@ufsc.br
Key words: Elderly; Social Conditions; Health of the Elderly. 


\section{INTRODUCTION}

The population of Brazil finds itself in a process of changing life expectancy, evidenced by increased numbers of elderly persons. ${ }^{1}$ In Rio Grande do Sul, the percentage of elderly people was $14.7 \%$ in 2011, the second highest elderly population in Brazil, behind only Rio de Janeiro (14.8\%), with both states having the highest aging rates in the country: 70.9 and 72.7 respectively. ${ }^{1}$ This large quantity of elderly people can be explained by the fact that Rio Grande do Sul is considered to be a state with good social economic, cultural and health conditions, ${ }^{2}$ increasing life expectancy still further.

In the context of this populational reality, the need to prevent diseases that affect the elderly, among which influenza stands out, due to it resulting in serious complications that can lead to death, is highlighted. Influenza is caused by globally distributed viruses. According to the World Health Organization (WHO), it is estimated that $5 \%$ to $15 \%$ of the population are affected and that, overall, influenza results in three million to five million severe cases and 250,000 to 500,000 deaths every year. ${ }^{3}$

The main intervention against this disease is vaccination. An annual campaign, carried out in Brazil every year since 1999 between the months of April and May, has contributed to the prevention of influenza among vaccinated groups, and has had an impact in reducing hospital admissions, drug costs in treating secondary infections, and preventable deaths. ${ }^{4}$

Most deaths from influenza occur among the elderly and, proportionally, complications occur much more frequently among people with comorbidities and a history of hospitalizations. However, there has been a reduction in the number of deaths from influenza among the elderly, which indicates that wide vaccination coverage is able to reduce the impact of mortality. ${ }^{5}$
These findings reinforce the need to understand the living conditions of the condition of elderly persons in order to plan and act preventively to address the needs of such people, creating the possibility of obtaining improved results in living conditions and health. In this context, living conditions are understood to be the unique position of each individual, arising from a large number of dimensions, involving economic, social, environmental, cultural and spatial, the results of an interactive process, which effects the individual and collective experience, and the momentary individuality of each environment. ${ }^{6}$

In this context, the aim of this study was to describe the multidimensional profile of the living conditions of a group of elderly participants of the vaccination campaign against influenza in the city of Uruguaiana, Rio Grande do Sul.

\section{METHOD}

A quantitative cross sectional study was performed, with data collection carried out between April and May 2010, during the national influenza vaccination campaign for the elderly. The study location was the city of Uruguaiana, Rio Grande do Sul, which has an elderly population of 13,694 people $(10.9 \%)^{7}$ and 13 Health Centers (HS).

Non-institutionalized elderly persons of both genders who lived in Uruguaiana, Rio Grande do Sul and used the city's health centers were invited to participate in the study. A convenience sample was used, based on probability sampling, and included a total of 225 elderly participants of the campaign against influenza in the 13 municipal health centers. The data collection instrument was applied when the elderly came to the HS to receive their influenza vaccination, with a 40 minute interval between respondents.

A maximum absolute variance proportion of 0.25 was established, resulting from $p(1-p)$ for $p=0.50$, with a level of confidence of $95.44 \%$ 
$(z=2)$. The approximate error of the inference of proportion did not exceed $1.87 \%$ in the study sample.

Data was collected by 29 students from the Nursing course of the Universidade Federal do Pampa (UNIPAMPA), who were previously trained. A structured questionnaire was applied, composed of closed questions on general data, housing, income, occupation, health, sociocultural aspects, spiritual aspects, aging and functional capacity. This questionnaire had been validated in a previous survey, conducted in the city of Curitiba-PR. ${ }^{8}$ The instrument used in this study covered the functional capacity of the elderly in activities of daily living and social participation. The initial questions were related to instrumental activities of daily living (IADL), more complex activities that require a greater degree of independence, or in other words, the ability to take care of one's own life. ${ }^{9}$ The questionnaire also asked about Basic Activities of Daily Living (BADLs), the performance of much simpler, personal and daily tasks.

The sample of 225 elderly individuals was exceeded, and 296 individuals were interviewed, resulting in a degree of confidence in the results of the study. Ultimately, however, the BioEstat 5.0 program was used to select and retain a convenience sample of 225 respondents.
Data was entered, tabulated and processed. It was then compiled, and a database with graphs and tables was created, providing simple statistical analysis of quantitative data.

The study was approved by the Ethics Research Committee of the Universidade Federal do Pampa, under registration $n^{\circ} 006 / 10$. All the participants signed a Free and Informed Consent Form and had their confidentiality guaranteed.

\section{RESULTS}

Of the 225 elderly persons interviewed, 140 $(62 / 2 \%)$ were women and $85(37.8 \%)$ were men. Elderly widows aged between 60 and 70 years old, with up to five children and who lived in brick houses with their children predominated, according to the data in table 1.

The variable income was grouped into fractions of the 2010 minimum wage, with a benchmark value of $\mathrm{R} \$ 510.00^{10}$ An individual and family income of up to one monthly minimum wage for elderly women and between one and two minimum wages for elderly men predominated. The results are displayed in Table 2. In addition to this data, it was found that income came mostly ( $\mathrm{n}=182$; $80.9 \%$ ) from retirement payments and pensions. 
Table 1. Distribution of elderly persons according to gender, age range, marital status, living arrangements and type of housing. Uruguaiana, RS, 2010.

\begin{tabular}{|c|c|c|c|c|}
\hline \multirow[t]{3}{*}{ Aspects evaluated } & \multicolumn{4}{|c|}{ Gender } \\
\hline & \multicolumn{2}{|c|}{ Female } & \multicolumn{2}{|c|}{ Male } \\
\hline & $\mathrm{n}$ & $\%$ & $\mathrm{n}$ & $\%$ \\
\hline Quantitative & 140 & 62.2 & 85 & 37.8 \\
\hline \multicolumn{5}{|l|}{ Age range } \\
\hline 60 to 70 years & 89 & 63.6 & 57 & 67.0 \\
\hline 71 to 80 years & 40 & 28.6 & 20 & 23.5 \\
\hline Older than 81 years & 11 & 7.8 & 8 & 9.4 \\
\hline \multicolumn{5}{|l|}{ Marital status } \\
\hline Single & 15 & 10.7 & 13 & 15.3 \\
\hline Married & 44 & 31.4 & 47 & 55.3 \\
\hline Separated & 13 & 9.3 & 4 & 4.7 \\
\hline Widowed & 65 & 46.4 & 16 & 18.8 \\
\hline Others & 3 & 2.1 & 5 & 5.9 \\
\hline \multicolumn{5}{|l|}{ Children } \\
\hline Up to five children & 73 & 52.1 & 51 & 60.0 \\
\hline More than five children & 21 & 15.0 & 16 & 18.8 \\
\hline Deceased children & 34 & 24.3 & 7 & 8.2 \\
\hline Does not have children & 9 & 6.4 & 8 & 9.4 \\
\hline \multicolumn{5}{|l|}{ Living arrangements* } \\
\hline Alone & 30 & 21.4 & 15 & 17.6 \\
\hline With partner & 43 & 30.7 & 58 & 68.2 \\
\hline With children & 62 & 44.3 & 29 & 34.1 \\
\hline With friends & 2 & 1.4 & 0 & 0.0 \\
\hline With relatives & 23 & 16.4 & 11 & 12.9 \\
\hline \multicolumn{5}{|l|}{ Type of housing } \\
\hline Brick house & 96 & 66.7 & 51 & 61.4 \\
\hline Wooden house & 48 & 33.3 & 32 & 38.5 \\
\hline Possesses basic sanitation & 102 & 78.5 & 47 & 61.8 \\
\hline Does not possess basic sanitation & 28 & 21.5 & 29 & 38.1 \\
\hline
\end{tabular}

${ }^{*}$ Question with multiple responses. 
Table 2. Distribution of elderly persons according to income. Uruguaiana, RS, 2010.

\begin{tabular}{lrrrrrrrr}
\hline & \multicolumn{3}{c}{ Individual income } & \multicolumn{5}{c}{ Family income } \\
& \multicolumn{3}{c}{ Gender } & \multicolumn{3}{c}{ Gender } \\
& \multicolumn{1}{c}{ Feminine } & Masculine & Feminine & Masculine \\
\multicolumn{1}{c}{ What is your income? } & $\mathrm{n}$ & \multicolumn{1}{c}{$\%$} & $\mathrm{n}$ & $\%$ & $\mathrm{n}$ & $\%$ & $\mathrm{n}$ & $\%$ \\
\hline Up to 1 minimum wage & 85 & 60.7 & 40 & 47.0 & 54 & 38.6 & 22 & 25.9 \\
Between 1 and 2 minimum wages & 19 & 13.6 & 25 & 29.4 & 36 & 25.7 & 25 & 29.4 \\
Between 2 and 3 minimum wages & 7 & 5.0 & 8 & 9.4 & 17 & 12.1 & 11 & 12.9 \\
More than 3 minimum wages & 8 & 5.7 & 8 & 9.4 & 14 & 10.0 & 12 & 14.1 \\
No income & 18 & 12.8 & 0 & 0.0 & 1 & 0.7 & 0 & 0.0 \\
Did not know & 0 & 0.0 & 0 & 0.0 & 9 & 6.4 & 14 & 16.5 \\
Did not answer & 3 & 2.1 & 4 & 4.7 & 9 & 6.4 & 1 & 1.2 \\
Total & 140 & 100.0 & 85 & 100.0 & 140 & 100.0 & 85 & 100.0 \\
\hline
\end{tabular}

In terms of current occupation, $80(57.1 \%)$ elderly women said they worked domestically in the home, while the majority of men did not work $(n=30 ; 35.3 \%)$.

In the area of health, the elderly persons were asked what health service they used the most. It was found that the majority ( $\mathrm{n}=178 ; 79.1 \%)$ of both men and women used the Sistema Único de Saúde ("the Unified Health System") (SUS). In terms of owning health insurance, $23(16.4 \%)$ elderly women and $11(12.9 \%)$ elderly men answered affirmatively. Nine $(6.4 \%)$ elderly women and six $(7.0 \%)$ elderly men said they used the private health services, although some elderly persons used SUS but had private health insurance.

In terms of evaluating the health care they received, most $(89(63.6 \%)$ of elderly women and $44(51.7 \%)$ of elderly men) considered it to be good. Thirty-five $(25.0 \%)$ elderly women described it as very good, five $(3.6 \%)$ said it was poor and four $(2.8 \%)$ said it was very poor. As for the elderly men, $20(23.5 \%)$ considered it very good, eight $(9.4 \%)$ said it was poor and four $(4.7 \%)$ said it was very poor.

In terms of perception of health, $84(60.0 \%)$ elderly women and 57 (67.0\%) elderly men described their health as good. Of the women, 23 (16.4\%) said their health was poor and $16(11.4 \%)$ said it was very poor. As for the elderly men interviewed, seven $(8.2 \%)$ said their health as poor and one $(1.2 \%)$ said it was very bad.

In terms of cultural aspects, when asked about their leisure time, both male and female elderly persons gave more than one answer, with the majority $114(50.6 \%)$ saying they watched TV, as well as going to the gym and walking (23.5\%). Another important finding was that the majority (67.1\%) of respondents reported they were not part of any social club, while $48(21.3 \%)$ took part in religious gatherings.

As for spirituality, all the elderly women (100\%) interviewed said they were religious, while of 85 elderly men interviewed four (4.7\%) said they were not religious. The vast majority said they believed in God, although different religions were mentioned. For this question, respondents provided more than one option, as there were elderly persons who mentioned believing in God and also in the Church. Most $(\mathrm{n}=122 ; 54.2 \%)$ of respondents were catholic, and $69(30.6 \%)$ were evangelical protestants.

As for the practicing of religion, the majority of respondents $(85.7 \%)$ said they were practicing. The percentage of elderly women who did not 
practice their religion was $14(10.0 \%)$, as opposed to $19(22.3 \%)$ elderly men. Most ( $\mathrm{n}=124 ; 55.1 \%)$ elderly men and women said they had become more religious as they grew older and 15 (6.6\%) said they believed less in religion.

In the present study, the elderly persons were also asked about aging and characteristics that promote longevity. The most commonly chosen alternatives were: eating properly, chosen by $121(28.7 \%)$ elderly persons, and healthy habits, mentioned by 83 (19.7\%). The least chosen alternative was destiny, which was only mentioned by $12(2.8 \%)$ respondents.

Regarding aging and other important aspects of life, the vast majority of elderly persons cited more than one option, with family ( $\mathrm{n}=144 ; 30.1 \%$ ) and health ( $\mathrm{n}=92 ; 19.2 \%)$ standing out. Among the least mentioned were: money $(\mathrm{n}=25 ; 5.2 \%)$ and leisure $(\mathrm{n}=13 ; 2.7 \%)$.

The elderly people also talked about the main problems they would like to see resolved in Brazil. The elderly women chose alcoholism and drugs $(\mathrm{n}=71 ; 26.5 \%)$ and crime, violence and corruption $(\mathrm{n}=44 ; 16.4 \%)$. Among the elderly men, $33(19.6 \%)$ also described alcoholism and drugs as the biggest problem, while another issue mentioned was political corruption $(n=25 ; 14.9 \%)$.

It was found that all the participants of the study were independent for BADLs and IADLS, as shown in table 3 .

Table 3. Responses of elderly persons of both genders, to questions related to instrumental activities of daily living (IADLs) and basic activities of daily living (BADLs). Uruguaiana, RS, 2010.

\begin{tabular}{|c|c|c|c|c|c|c|c|c|}
\hline & \multicolumn{2}{|c|}{ Without help } & \multicolumn{2}{|c|}{$\begin{array}{l}\text { With some } \\
\text { help }\end{array}$} & \multicolumn{2}{|c|}{ Incapable } & \multicolumn{2}{|c|}{$\begin{array}{l}\text { Did not } \\
\text { respond }\end{array}$} \\
\hline & F & M & F & $\mathrm{M}$ & $\mathrm{F}$ & M & $\mathrm{F}$ & M \\
\hline \multicolumn{9}{|l|}{ IADL } \\
\hline Are you capable of going shopping? & 112 & 72 & 19 & 5 & 3 & 3 & 6 & 5 \\
\hline $\begin{array}{l}\text { Are you capable of using the } \\
\text { telephone? }\end{array}$ & 109 & 61 & 16 & 3 & 6 & 9 & 9 & 12 \\
\hline $\begin{array}{l}\text { Are you capable of washing and } \\
\text { ironing your own clothes? }\end{array}$ & 123 & 64 & 7 & 6 & 7 & 7 & 3 & 8 \\
\hline $\begin{array}{l}\text { Are you capable of going out alone } \\
\text { to distant places using some form of } \\
\text { transport (without the need for special } \\
\text { planning)? }\end{array}$ & 113 & 75 & 20 & 5 & 3 & 3 & 4 & 2 \\
\hline \multicolumn{9}{|l|}{ BADL } \\
\hline Can you take a shower? & 133 & 78 & 0 & 1 & 0 & 0 & 7 & 6 \\
\hline Can you dress yourself? & 135 & 81 & 0 & 1 & 1 & 0 & 4 & 3 \\
\hline Can you go to the bathroom? & 136 & 81 & 0 & 1 & 1 & 0 & 3 & 3 \\
\hline Can you go from the bed to the chair? & 134 & 80 & 2 & 1 & 0 & 0 & 4 & 4 \\
\hline Can you control your feces and urine? & 125 & 79 & 12 & 3 & 0 & 0 & 3 & 3 \\
\hline Can you feed yourself? & 137 & 82 & 0 & 0 & 0 & 0 & 3 & 3 \\
\hline
\end{tabular}

$\mathrm{F}=$ female; $\mathrm{M}=$ male. 


\section{DISCUSSION}

The multidimensional profile of the elderly persons in this study corroborates data from other studies about the health of older people, which also highlighted the predominance of women. ${ }^{11-19}$ Elderly women attend health services more often, which was confirmed in a study conducted in the city of Recife in the state of Pernambuco, which suggests that the widowed status of most of the elderly female respondents $(71.7 \%)$ is due the fact that women have a longer life expectancy than men because they take better care of their health. ${ }^{20}$ Another study in Santa Catarina found that as well as women taking better care of their health, men are more reluctant to seek treatment from health services to prevent disease, and therefore die sooner. ${ }^{21}$

In this study, the predominant age group (60-70 years) proves that the statistical life expectancy of people from this region reaches approximately 75 years. It is believed that this data is associated with the improved health, socioeconomic and social conditions of the state of Rio Grande do Sul. ${ }^{2}$ In terms of age group, it is worth mentioning that the percentage of men older than 81 years in this study was 1.2 times greater than the percentage of women, suggesting that men live longer. This data contradicts several studies ${ }^{20,21}$ which show that women have greater longevity.

In terms of the marital status of the elderly persons studied, women found it more difficult to remarry after widowhood, unlike older men. A study carried out in Fortaleza found that widowhood predominates among women, whereas older men tend to remain married. ${ }^{22}$

The results regarding number of children reveal the historical decrease in the size of families. In terms of family structure there was a high rate of elderly persons living with their children, which can stimulate sociability. It is worth noting that the results of this study confirmed that men, who have a higher rate of remarriage, live mostly with their partners. ${ }^{22}$
It was found that the types of housing described in this study reflect the positive socio-economic and health conditions of the state of Rio Grande do Sul. A study conducted in another state in the south of Brazil revealed similarly good sanitary and housing conditions. ${ }^{21}$

Data relating to the income of the elderly persons investigated corroborated the results of a survey performed in Santa Catarina, in which, of 94 elderly individuals aged 80 or older, the majority $(93.25 \%)$ received up to two minimum wages per month. ${ }^{21}$ Another study in Foz do Iguaçu, Paraná also highlighted the low purchasing power of the elderly ${ }^{15}$ describing both the poor financial condition of elderly people in Brazil, and their vulnerability. According to a study conducted across seven locations in Brazil, elderly persons with an income below the minimum wage suffer from more chronic diseases and those with an income of between one and three minimum wages are less satisfied with their memory and ability to solve everyday problems. ${ }^{14}$

Moreover, the low income of elderly women may be influenced by historical features that have remained from childhood and adolescence, in which the women helped with household chores and were raised to be housewives, mothers and wives. ${ }^{23,24}$ In terms of family income, the minimum salary was prevalent and a small percentage of the elderly had no income, which differs from a study conducted in seven Brazilian cities, where the average family income of the elderly was identified as $3.9( \pm 4.9)$ minimum wages. ${ }^{14}$

These findings highlight the importance of social security benefits, pensions and retirement plans for the survival of the elderly. However, this situation may have consequences on the structure of society, such as an increase in the number of elderly persons who provide for their families, as in many cases adult children return to the homes of their elderly parents when experiencing economic instability, which often arises from unemployment. ${ }^{22}$ 
In terms of occupation, the importance of the relationship between quality of life and the ability to perform domestic chores and feeling useful stands out as a facet of possessing physical control over one's own body. ${ }^{20}$

With regard to health care, a study of 109 elderly persons conducted in João Pessoa found that the majority $(82.6 \%)$ used SUS, and that the higher the income of the person, the lower the degree of intense usage of the service. ${ }^{16}$ The elderly persons in the present study were satisfied with the health care they received, a finding which differs from the aforementioned study, ${ }^{16}$ where it was found that there is lack of resources for the suitable care of persons aged over 60 years.

With regard to health status, the majority $(62.6 \%)$ of elderly persons reported having good health, supporting a study carried out in Santa Catarina, where older people also said they had good health, with $36.78 \%$ stating that they suffered from a chronic disease. In addition, 81.61\% said they were very satisfied with their lives, data that may be explained by the fact that the study dealt with elderly individuals who had better access to basic sanitation, infrastructure and health services. ${ }^{21}$

In terms of leisure, it is worrying to see how few of the elderly people surveyed practiced physical activities, in comparison with those who preferred to watch TV. The habit of exercising, within reasonable limits, is an important factor for the stimulation of various organs, reducing morbidity during life and bringing many other benefits such as greater flexibility, as well as making elderly persons more resistant to the changes that come with old age. ${ }^{20}$ Another study that considered leisure activities found that most elderly persons took part in recreational activities such as parties, bars and mothers' unions. ${ }^{21}$

In terms of faith, a study carried out in Foz do Iguaçu-PR found that religiosity among the elderly is usually more pronounced than among younger people, suggesting that "with increasing age, spirituality is an important source of emotional support, benefiting physical and mental health". ${ }^{15}$ In the present study, the majority of older people became more religious over the years, which can be explained by the fact that aging leads to biological changes, diseases and changes in emotional state.

In terms of religion, a study ${ }^{25}$ carried out in São Paulo also identified that the majority of elderly persons are catholic $(71.1 \%)$ or evangelical protestants $(19.2 \%)$. In addition, older women were more dedicated to the practicing of religion than man, as the number of older men surveyed in this study that said they were not religious was three times greater than the number of elderly women.

The most important aspects in the lives of the elderly persons surveyed highlighted the importance of family, because of emotional contact, care and family relationships themselves, corroborating findings in literature. . $^{5,22,26}$

In terms of IADLs, the elderly persons surveyed in the present study displayed Independence, an important finding, considering that mobility is essential for the execution of physical activities of daily life. ${ }^{20}$ Another aspect that can be inferred from this item is that elderly women, when aging, suffer greater biological debilitation than men. ${ }^{15}$ A study ${ }^{17}$ carried out in the city of Pelotas, Rio Grande do Sul, found that the majority of elderly individuals were dependent in terms of movement, both for using some form of transport (82.4\%), and for shopping $(83.9 \%)$.

The elderly persons in the present study were also independent for BADLs, agreeing with another study where walking, getting up from a chair, getting in and out of bed, bathing, eating, and dressing oneself were classified as easy by the elderly persons surveyed. ${ }^{19}$ Regarding difficulties in carrying out some activities, the elderly persons had more difficulty performing activities such as "running", "heavy lifting" and "bending down/ kneeling". ${ }^{19}$ The findings in relation to activities of daily living are related to cultural aspects, where the woman historically takes care of the housework and the man does the heavier work. ${ }^{18}$

In terms of the ability of the elderly persons to control their sphincters, in the present study elderly women had more difficulty than elderly men, with 8.6\% (12) of women displaying partial 
dependence for this ability, compared to 3.5\% (3) of men. Physiologically, there was no difference between men and women in the structural and functional changes in the genitourinary system, other than there was a higher prevalence of increased urination and incontinence among women. ${ }^{27}$ In contrast, bowel functions were little affected during aging due to a high functional reserve, but in most frail elderly persons there are problems such as impaction and fecal incontinence of a multifactorial nature. ${ }^{28}$

The information presented here represents a profile of a group of elderly persons who took part in an influenza vaccination campaign, which was the aim of this study. However, as the study deals with an ascribed population, care must be taken when generalizing the findings.

Cross-sectional studies present limitations when evaluating the temporal nature of the factors studied. Nonetheless, the present study represents a multi-dimensional profile of elderly persons who participated in an influenza vaccination campaign at a given time.

\section{CONCLUSION}

Knowledge about the living conditions of the elderly persons studied, participants in a vaccination campaign, enables health care teams and managers to develop subsidies for the implementation and the development of appropriate public policies for this population group, aimed at improving their quality of life.

The new demographic and epidemiological reality evidenced by the quantitative increase of the elderly implies the need for changes in public health care policy for this population. The multidimensional profile identified in this study of elderly participants inform a campaign against influenza contributes to health planning.

\section{REFERENCES}

1. Instituto Brasileiro de Geografia e Estatística. Síntese de indicadores sociais: uma análise das condições de vida da população brasileira 2012. Brasília, DF: IBGE; 2012

2. Gottlieb MGV, Schwanke CHA, Gomes I, Cruz IBM. Envelhecimento e longevidade no Rio Grande do Sul: um perfil histórico, étnico e de morbi-mortalidade dos idosos. Rev Bras Geriatr Gerontol 2011;14(2):365-80.

3. World Health Organization. Global Alert and Response [Internet]. Geneva: WHO. 2014- .Global Influenza Surveillance and Response System; 2014 [acesso em 17 jan 2015]; [aproximadamente 2 telas]. Disponível em: http://www.who.int/influenza/gisrs_ laboratory/en/

4. Brasil. Ministério da Saúde. Informe técnico: Campanha Nacional de Vacinação contra a Influenza. Brasília, DF: Ministério da Saúde; 2014.

5. Centers for Disease Control and Prevention, Morbidity and Morality Weekly Report. Prevention and control of seasonal influenza with vaccines: recommendations of the advisory Committee on Immunization Practices-United States, 2013-2014. Atlanta: CDC; 2013. p. 1-43. Recommendations and Reports 62 (RR-07).
6. Hammerchmidt KSA. Políticas públicas locais de saúde: desdobramentos na condição de vida da população de Curitiba, PR [dissertação]. Curitiba: Unifae, Centro Universitário Franciscano do Paraná; 2007.

7. Instituto Brasileiro de Geografia e Estatística [Internet]. Rio de Janeiro: IBGE. 1995- . Censo demográfico 2010; [acesso em 10 set 2013]; [aproximadamente 2 telas]. Disponível em: http:// www.ibge.gov.br/home/estatistica/populacao/ censo2010/default.shtm

8. Paiva MF. Idoso em Curitiba: avaliação das condições de vida. Curitiba: IPPUC; 2006.

9. Moraes EN, Moraes FL, Keller A, Ribeiro MTF. Avaliação clinico-funcional do idoso. In: Moraes EN. Princípios básicos de geriatria e gerontologia. Belo Horizonte: Coopmed; 2008. p. 63-84.

10. Brasil. Lei no 12.255 de 15 de junho de 2010. Dispõe sobre o salário mínimo a partir de $1^{\circ}$ de janeiro de 2010, estabelece diretrizes para a política de valorização do salário mínimo entre 2012 e 2023 e revoga a Lei no 11.944, de 28 de maio de 2009. Diário Oficial da União. 16 Junho 2010. 
11. Abreu ICME, Guimarães GM, Silva RR, Ribeiro SMR, Martino HSD. Baixa renda entre os idosos participantes da terceira idade está associada à qualidade da dieta. Braz J Food Nutr 2013;24(3):349-57.

12. Marques EIW, Petuco VM, Gonçalves CBC. Motivos da não adesão ao tratamento médico prescrito entre os idosos de uma unidade de saúde da família do município de Passo Fundo - RS. Rev Bras Ciênc Envelhec Hum 2010;7(2):267-79.

13. Sposito G, D’Elboux MJ, Neri AL, Guariento ME. A satisfação com a vida e a funcionalidade em idosos atendidos em um ambulatório de geriatria. Ciênc Saúde Coletiva 2013;18(12):3475-82.

14. Pinto JM, Neri AL. Doenças crônicas, capacidade funcional, envolvimento social e satisfação em idosos comunitários: Estudo Fibra. Ciênc Saúde Coletiva 2013;18(12):3449-60.

15. Faller JW, Melo WA, Versa GLGS, Marcon SS. Qualidade de vida de idosos cadastrados na Estratégia Saúde da Família de Foz do Iguaçu- PR. Esc Anna Nery Rev Enferm 2010;14(4):803-10.

16. Araújo VR, Valença AMG, Rocha AV. Saúde do idoso na Atenção Básica de Saúde o município de João Pessoa: o olhar do usuário. Rev Bras Ciênc Saúde 2012;16(2):195-204.

17. Duca GFD, Silva MC, Hallal PC. Incapacidade funcional para atividades básicas e instrumentais da vida diária em idosos. Rev Saúde Pública 2009;43(5):796-805.

18. Benedetti TRB, Borges LJ, Petroski EL, Gonçalves LHT. Atividade física e estado de saúde mental de idosos. Rev Saúde Pública 2008;42(2):302-7.

19. Ohlweiler ZNC, Areosa SVC, Wichmann FMA, Pedralli ML, Benitez LB, Witczak MVC, et al. Estudo multidimensional das condições de vida do idoso que frequenta os serviços da Unisc campus Santa Cruz do Sul, RS. Rev Kairós 2007;10(1):175-87.
20. Cartacho HGO, Silva EAPC, Santos ARM, Siqueira PGBS, Pazzola CM, Freitas CMSM. Percepção de idosas sobre o envelhecimento com qualidade de vida: subsídio para intervenções públicas. Rev Rene 2012;13(1):158-68.

21. Farias RG, Santos SMA. Influência dos determinantes do envelhecimento ativo entre idosos mais idosos. Texto \& Contexto Enferm 2012;21(1):167-76.

22. Mota FRN, Oliveira ET, Marques MB, Bessa MEP, Leite BMB, Silva MJ. Família e redes sociais de apoio para o atendimento das demandas de saúde do idoso. Esc Anna Nery Rev Enferm 2010;14(4):833-8.

23. Lisboa CR, Chianca TCM. Perfil epidemiológico, clínico e de independência funcional de uma população idosa institucionalizada. Rev Bras Enferm 2012;65(3):482-7.

24. Clares JWB, Freitas MC, Almeida PC, Galiza FT, Queiroz TA. Perfil de idosos cadastrados numa unidade básica de saúde da família de Fortaleza-CE. Rev Rene 2011;12 (n. esp.):988-94.

25. Duarte YAO, Lebrão ML, Tuono VL, Laurenti R. Religiosidade e envelhecimento: uma análise do perfil de idosos do município de São Paulo. Saúde Colet 2008;5(24):173-7.

26. Pedreira LC, Lopes RLM. Vivência do idoso dependente no domicílio: análise compreensiva a partir da historicidade heideggeriana. Rev Eletrônica Enferm [Internet] 2012 [acesso em 26 set 2013];14(2):304-12. Disponível em: http://dx.doi. org/10.5216/ree.v14i2.10313

27. Maciel A, Meira MA, Dias RC, Marques LM. Incontinência urinária. In: Moraes EN. Princípios básicos de geriatria e gerontologia. Belo Horizonte: Coopmed; 2008. p. 423-37.

28. Moraes EM, Santos RR, Silva ALA. Fisiologia do envelhecimento aplicada à prática clinica. In: Moraes EN. Princípios básicos de geriatria e gerontologia. Belo Horizonte: Coopmed; 2008. p. 37-59. 